\title{
THE EFFECT OF PRACTICUM METHOD ON REPRESENTATIONABILITY AND COGNITIVE LEARNING OUTCOMES
}

\author{
Darlen Sikumbang $^{1}$, Dewi Lengkana ${ }^{2}$, Rita Foorantika ${ }^{3}$ \\ 1,2,3 Program Studi Pendidikan Biologi, FPMIPA, FKIP Universitas Lampung \\ Bandar Lampung \\ ${ }^{3}$ ritafoorantika@gmail.com
}

Accepted: March, 4, 2020

Published: May, 6, 2020

DOI: $10.21107 / j p s . v 7 i 1.6730$

\begin{abstract}
The existence of laboratory activities in or outside the room can facilitate students in visualizing the imagination to be real. This study aims to determine the effect of using practicum methods on the students' representation ability and cognitive learning outcomes on the subject matter Classification of Living Things. This research was conducted at Junior High School 26 Bandar Lampung. The method uses a quasi-experimental method with Pretest-Posttest NonEquivalent Control Group Design. A random sampling technique took the sample in this study, and the research subject uses class VII A as experiment class and VII B as a control class. The data in this study are quantitative data that were analyzed using the Independent sample t-test. Based on the results of this study, the effect of practicum methods on the students' representation ability is level 1 , and 2 before the treatment then increases to levels 3,4 , and 5 after the practicum with the student answers that have made elements representation such as tables, graphs, icons, and images. Therefore, practicum methods can be used by science educators to facilitate students in conceptual understanding by using elements of representation.
\end{abstract}

Keywords: Cognitive Learning Outcomes, Practicum Method, Representation Ability

\footnotetext{
${ }^{3}$ Corresponding Author
} 


\section{Introduction}

Improving the quality of education is done to improve the learning system in a nation. Knowledge determines the level of progress of a nation by developing capabilities and shaping the growth of the country to establish the nation's potential. Education plays an essential and strategic role in producing quality human resources that will build the society and the State (Permendikbud No. 20, 2003).

Nowadays, interest and attention to laboratory activities as a means of teaching science have developed, especially in secondary schools. It can see in the curriculum developed at this time, where practicum is one alternative to provide learning experiences to students. Bettencourt (in Hutagaol, 2013) said that teaching is not transferring knowledge from teachers to students, but an activity that allows students to build their knowledge. Therefore, in science learning activities, all information should not be conveyed in a finished form. Still, through practicum activities, students try to find information independently to develop the ability of representation. Piaget further argued that knowledge is not gained passively by someone but through action. Even children's cognitive development depends on how far they actively manipulate objects and interact with their environment (Ruseffendi, 1996). In other hand, Laboratory activity can train students to observe, understand, classify, and conclude a problem. Students can do their activities under the guidance of educators to follow the steps of the scientific method (Zahrah, Abdul, \& Hasan, 2017).

Hudiono (2002) (in Hutagaol, 2013) states that representations such as tables, pictures presented to students, as a companion or complement in the delivery of material. Whereas according to Piaget, the age of junior high school students is at the stage of concrete operations, right to provide many opportunities to manipulate real objects, make models, diagrams, and others, as an intermediary tool for formulating and presenting abstract concepts (Ruseffendi, 1996). In addition, Fitriyana (2013) argues that through practicum activities, students will see for themselves the events that have been learned through theory so that they will give a more profound impression in their minds. The existence of practicum activities in or outside the lab can facilitate students in visualizing the imagination to be real (Aeni, 2017). The activity of visualizing is a form of understanding of students in representing a learning concept. Visualization deals with external representations, where the information display is systematic and focused in the form of drawings, charts, diagrams, tables, and the like. Visualization performance requires meta visualization that involves the ability of students to obtain, monitor, integrate, and expand knowledge with representation (Gilbert, 2005). Ruseffendi (1996) states that manipulating concrete objects in learning activities is very important because by manipulating concrete objects students can better understand concepts

Based on the results of a preliminary study, there are several findings, i.e., learning activities still rarely accompanied by practical exercises. Educators even tried to invite active students into learning activities with discussion. Educators do the question and answer as a form of interaction between educators and students, but the action only takes place in one direction. Secondly, in learning science material, students have not used much representation in explaining a concept. Thirdly, students only focus on memorizing nor understanding the learning material. That affects the students learning outcomes, wherein students cannot interpret their thoughts to answer questions.

The ability of representation is a useful description to provide accurate and efficient information because specific information is difficult to read (Ainswort, 2006). In the Classification of Living Things, learning using multi representations is used with the aim that students can display their understanding in various forms of external representations such as drawings, diagrams, 2D or 3D models, and symbols. Practicum learning methods believed to be appropriate for use because the material Classification of Living Things is material that is a real object and is very close to students. Students can observe phenomena related to the Classification of Living Things directly.

\section{Research Methods}

This research was carried out at SMP Negeri 26 Bandar Lampung in the 1st semester. The population in this study were all seventh-grade with 213 students. In this study, sampling uses random sampling techniques because of the way to determine samples in an arbitrary population unit without strata discrimination (Sugiyono, 2010). This research design is a quasi-experimental with a non-equivalent pretest-posttest control group design (see table 1). 
Sikumbang, Lengkana, \& Foorantika

Table 1. Non-equivalent Group Pretest-Posttest Design

\begin{tabular}{cccc}
\hline Group & Pretest & $\begin{array}{c}\text { Independent } \\
\text { Variable }\end{array}$ & Posttest \\
\hline $\mathbf{E}$ & $\mathrm{O}_{1}$ & $\mathrm{X}$ & $\mathrm{O}_{2}$ \\
\hline $\mathbf{C}$ & $\mathrm{O}_{3}$ & - & $\mathrm{O}_{4}$ \\
\hline
\end{tabular}

Information:

$\mathrm{E} \quad=$ Experimental group

$\mathrm{C}=$ Control group

$\mathrm{X}=$ Treatment in the experimental class

using Practicum learning methods

$\mathrm{O}_{1,3}=$ Pretest

$\mathrm{O}_{2,4} \quad=$ Posttest

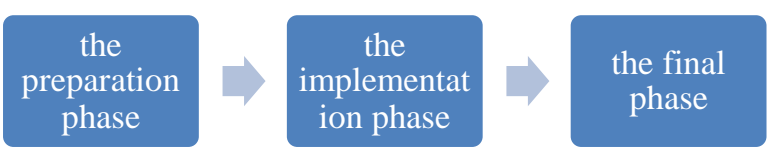

Figure 1. Research Flowchart

This study consists of three stages, i.e., (1) the preparation, (2) the implementation, and (3) the final (see figure 1). There is nine activity in the first stage, i.e., 1) the researcher observes the suitable school for conducting research; 2) make a preliminary study for the selected school; 3) seeing the school to obtain relevant information to support research implementation; 4) determine the research sample for the experimental class and the control class, where the experiment class will train with the practicum method while the control class uses the discussion learning method; 5) compile learning tools consisting of Syllabus, Lesson Plan, and Student Worksheet; 6) make an evaluation instrument of representation ability and learning outcomes; 7) conduct a validation test of research instruments to students; 8) analyze the results of the validity test and instrument reliability test; and 9) revising research instruments.

Second stages, the activities carried out at the implementation treatment to experiment and control class. Pretest gave before learning activity to know the initial ability of students. Final Phase, the activities carried out at this last stage include processing the data of the results of the pretest and posttest.

The type of data in this study is quantitative data, which is an increase in the ability of students' representation and cognitive learning outcomes in the Classification of Living Things material obtained from the pretest and posttest and N-gain values. Quantitative data collected from the pretest and posttest were analyzed using the Independent sample t-test.

\section{Result and Discussion}

The results of research conducted at SMP Negeri 26 Bandar Lampung obtained data on the Representation Ability of Students in the form of scores (see table 2).

Table 2. Statistical Test Results for Representation Ability

\begin{tabular}{|c|c|c|c|c|c|c|c|c|}
\hline \multirow{2}{*}{ Data } & \multirow{2}{*}{ Class } & \multirow{2}{*}{$\begin{array}{c}\text { Mean } \pm \text { std } \\
\text { deviation }\end{array}$} & \multirow{2}{*}{$\begin{array}{l}\text { Normality test } \\
\text { (Sig. 2-tailed) }\end{array}$} & \multirow{2}{*}{$\begin{array}{l}\text { Homogeneity } \\
\text { test (Sig.) }\end{array}$} & \multicolumn{4}{|c|}{ Independent sample t-test } \\
\hline & & & & & $\mathbf{t}_{\text {arithmetic }}$ & $\mathbf{t}_{\text {table }}$ & df & Sig. (2-tailed) \\
\hline \multirow[t]{2}{*}{ Pretest } & $E$ & $32,33 \pm 11,19$ &, 390 & \multirow{2}{*}{, 066} & \multirow{6}{*}{10,275} & \multirow{6}{*}{2,00172} & \multirow{6}{*}{58} & \multirow{6}{*}{$\begin{array}{c}\text { Sig. (2-tailed) } \\
, 000<0,05\end{array}$} \\
\hline & $\mathrm{K}$ & $37,50 \pm 8,78$ &, 106 & & & & & \\
\hline \multirow[t]{2}{*}{ Posttest } & $\mathrm{E}$ & $79,00 \pm 11,25$ & ,712 & \multirow{2}{*}{, 262} & & & & \\
\hline & $\mathrm{K}$ & $47,33 \pm 13,24$ & ,744 & & & & & \\
\hline \multirow[t]{2}{*}{$N$-gain } & $\mathrm{E}$ & $0,69 \pm 0,18$ & ,403 & \multirow{2}{*}{082} & & & & \\
\hline & $\mathrm{K}$ & $0,15 \pm 0,23$ &, 512 & & & & & \\
\hline
\end{tabular}

Note: $\mathrm{E}=$ Experiment (Practicum Method); $\mathrm{K}=$ Control (Discussion Method)

The results of the normality and the homogeneity test in the experiment and the control class show significance values greater than 0.05 (see table 2). It means that the data are normal and homogeneous distributed. The results of the analysis of the effect of using practicum methods on student representation ability showed a value of 0,000 that was smaller than 0.05 \{ Sig. (2-tailed) $<0.05\}$ with the value of $t$ calculate $>t$ table means that $\mathrm{H}_{0}$ is rejected, and $\mathrm{H}_{1}$ is accepted so that there is an influence of the use of practicum methods on student's representational abilities. According to Ainswort (2006) that the representation ability is a useful depiction to provide concrete and efficient information because specific information is difficult to read. Students can display their understanding in various forms of external representation so that learning activities can occur if students can respond to the stimulus in the learning process with practicum methods.

The percentage of the dynamics of changes in the representation ability of students between the experimental and control classes has differences that can be seen from the comparison of the $\mathrm{N}$-gain values of the student's representation ability. The percentage change in the $\mathrm{N}$-gain dynamics in the experiment class is most significant in the medium category, while for the control class, the highest is in a low category. Thus, the percentage of the dynamics of changes in the $\mathrm{N}$-gain value of the representation ability of 
students who learn by using the highest practicum method in the high category compared to students who use the most top discussion method in the low category as shown in Figure 2. When students are asked to think and reason about the concept of science and communicate the results of their thoughts verbally and in writing, then with the help of student representation can gain a more precise and more convincing understanding. The representation can help students in explaining concepts or ideas and makes it easy for students to get strategies in solving problems (Hutagol, 2013). Visualizing the results of the practicum and interpreting concepts or theories obtained from the results of the practicum in a mathematical form in the form of equations or formulas can improve the ability of abstract representation of students.

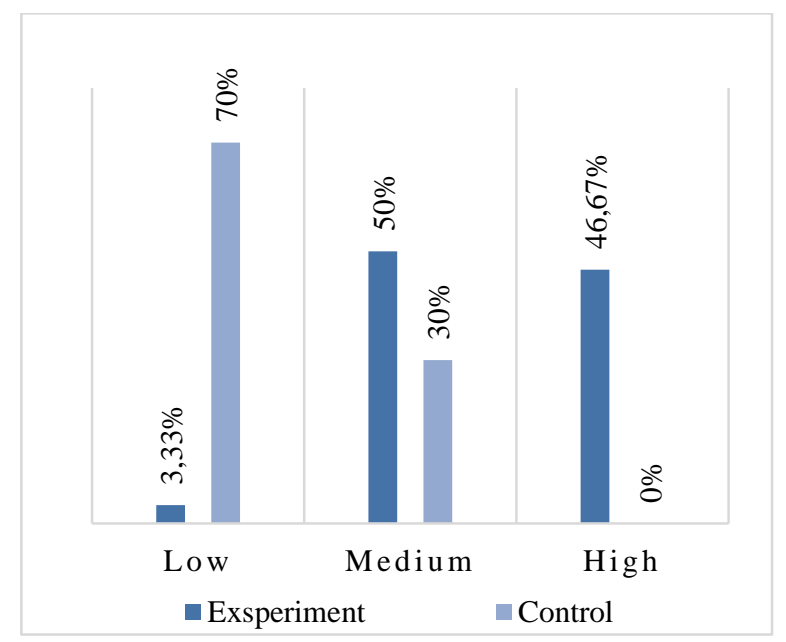

Figure 2. Percentage of Dynamics of Change in N-gain Value for the Representation Ability of Experiments and Control Classes

Recapitulation of the increase in the level of representation ability in the pretest and posttest questions of the experiment class achieves at level 1 , which means students were not able yet to answer test questions by using representation elements. Whereas, for posttest answers, most students achieved were at level 5. Students were required to interpret abstract concepts that were obtained and then projected into tables, symbols, pictures, and other representation elements. After learning with practicum methods, students have made representational elements such as pictures, icons, graphs, and tables in answering each question. According to Schoenfeld (1987) suggests that knowledge of metacognitive and cognitive skills will help students build thought plans that involve strategies, skills, and procedures to solve a given problem. This new thought plan connects to understanding the relevant concepts that will use. It is supported by Malik (2015), which states that the learning process of students who learn with concrete objects directly, they can find their facts and theories through group discussions. According to Jonathan \& Justin (2010), in principle, practicum methods can bring students to natural events and can develop students' understanding by building knowledge about nature more steadily.

The representation ability of students after being treated with practicum methods has the results of varying levels of improvement-the rubric of the representation ability, where represented in Table 3.

Table 3. Representation Ability Assessment Rubric

\begin{tabular}{cl} 
Score & \multicolumn{1}{c}{ Criteria } \\
$\mathbf{5}$ & $\begin{array}{l}\text { Correct answers, correct explanations and } \\
\text { representation elements such as pictures, icons, } \\
\text { symbols, labels, graphics, or tables are true and } \\
\text { complete } \\
\text { Correct answers, correct explanations and } \\
\text { representation elements such as pictures, icons, } \\
\text { symbols, labels, graphics, or tables are incorrect } \\
\text { and incomplete } \\
\text { Correct answers, inadequate explanation and } \\
\text { representation elements such as pictures, icons, } \\
\text { symbols, labels, graphics, or tables are true and } \\
\text { complete } \\
\text { The answers are not correct, the explanation is } \\
\text { not correct, and the representation elements } \\
\text { such as pictures, icons, symbols, labels, } \\
\text { graphics, or tables are incorrect and incomplete } \\
\text { Incorrect answers, incorrect explanations and } \\
\text { representation elements such as pictures, icons, } \\
\text { symbols, labels, graphics, or tables that are } \\
\text { incorrect and incomplete }\end{array}$ \\
\hline
\end{tabular}

Examples of student's answers to question number 3 in the level 1 category are shown in Figure 3.

Problem 3. Cat and cat paintings are two different objects, both of which have different characteristics. Which of the two objects is living and non-living beings? Draw in the form of a table the difference in features between living things and non-living things!

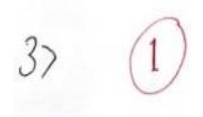

Figure 3. The answer to Question Number 3 at Level 1

Students who are at level 1 have an incorrect answer with a wrong explanation and do not use the representation element as the answer. It might be because students have not used representation elements such as pictures, tables, icons, and graphics in learning that have been done before, and students do not understand the questions posed so that they skip to answer question number 3 . 


\section{Sikumbang, Lengkana, \& Foorantika}

Example responds to students for question number 3 , with the level 2 category shown in Figure 4.

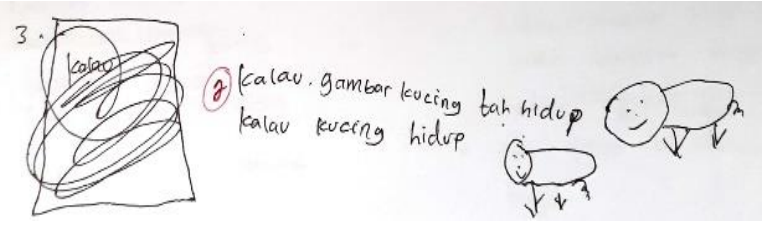

Figure 4. The answer to Question Number 3 at Level 2

Students who are at level 2 means that the answers that are displayed are not correct with inaccurate explanations and the lack of representation elements used. The category of students' answers at level 2 is seen from the responses of students who classify living things and non-living things wrong in writing the characteristics of living things and inanimate objects and have not used the element of representation in answering questions. Examples of students' answers to question number 3 in the level 3 category are shown in Figure 5.

\begin{tabular}{|l|l|}
\hline \multicolumn{1}{|c|}{ keterangan } & \multicolumn{1}{|c|}{ ciri-cininya } \\
\hline Lukisan kucing (BTH) & $\begin{array}{l}\text { 1. tidak bisa bergerak } \\
\text { 2. tidak berkembang biak } \\
\text { 3. tidak bernapas }\end{array}$ \\
\hline kucing (Mh) & $\begin{array}{l}\text { 1. bisa bergerak } \\
\text { 2i bisa berkembang biak } \\
\text { 3. bisa bernapas }\end{array}$ \\
\hline
\end{tabular}

Figure 5. The answer to Question Number 3 at Level 3

Students who are at level 3 mean that the answers displayed are correct with inadequate explanations, but the representation elements used are correct, which means the responses of students already use representation elements such as tables. The answer categories have been able to write the column headings and take into account the number of columns and rows and write at least 2-3 the number of characteristics of living things and nonliving objects. Examples of student's answers to question number 3 in the level 4 category are shown in Figure 6.
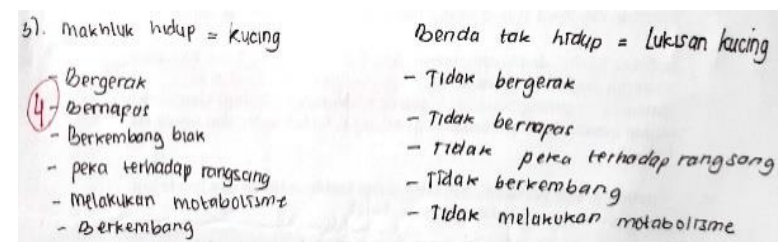

Figure 6. The answer to Question Number 3 at Level 4

Students who are at level 4 means that the answers shown are correct with the right explanation, but the students are lacking in using representation elements such as tables. The correct category of student's solutions seen from the answers written already classifies living things and inanimate objects and then the minimum number of features that must be written at least 5-7 characteristics. Examples of student's responses to question number 3 in the level 5 category are shown in Figure 7.

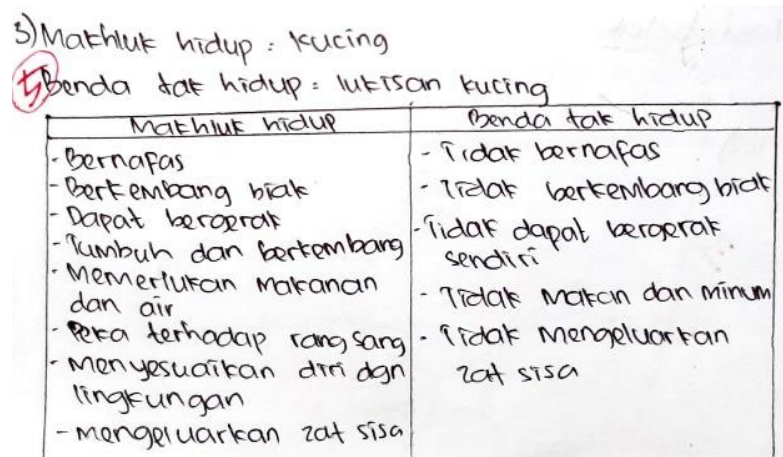

Figure 7. Answer to Question Number 3 at Level 5

Students who are at level 5 means that the answers are displayed correctly with the right explanation and the correct and complete representation elements. Answer category level 5 students indicate that they can classify living things and non-living objects, write column headings and calculate the number of columns and rows to answer questions and write the characteristics of living things and non-living things in full.

It shows that the using practicum methods affect the representation ability of students, where the average student is at level 1 and 2 before being given treatment then has increased to levels 3, 4, and 5 with the answers of the student who have made elements of representation such as tables, graphics, icons, and images. The use of practicum methods as a learning method is the right method to improve student's representational ability compared to using discussion methods because of using practicum methods. Students who do not understand how to convey accepted concepts are required to be able to interpret these concepts in the form of images, tables, or other representation elements so that the idea will facilitate students in recording the information received. According to Rosengrant (2007), representations are used not only to help students solve problems but also to evaluate their work.

Data scores of Cognitive Learning Outcomes obtained from test results before and after the application of Practicum methods in the Experiment and Control class. The results of the statistical test analysis are shown in Table 4. 
Table 4. Statistical Test Results for Cognitive Learning Outcomes

\begin{tabular}{|c|c|c|c|c|c|c|c|c|}
\hline \multirow{2}{*}{ Data } & \multirow{2}{*}{ Class } & \multirow{2}{*}{$\begin{array}{l}\text { Mean } \pm \text { std } \\
\text { deviation }\end{array}$} & \multirow{2}{*}{$\begin{array}{l}\text { Normality test } \\
\text { (Sig. 2-tailed) }\end{array}$} & \multirow{2}{*}{$\begin{array}{l}\text { Homogeneity } \\
\text { test (Sig.) }\end{array}$} & \multicolumn{4}{|c|}{ Independent sample t-test } \\
\hline & & & & & $\mathbf{t}_{\text {arithmetic }}$ & $\mathbf{t}_{\text {table }}$ & df & Sig. (2-tailed) \\
\hline \multirow[t]{2}{*}{ Pretest } & $E$ & $52,83 \pm 15,63$ &, 765 & \multirow{2}{*}{,423 } & \multirow{6}{*}{3,596} & \multirow{6}{*}{2,00172} & \multirow{6}{*}{58} & \multirow{6}{*}{$\begin{array}{c}\text { Sig. (2-tailed) } \\
, 001<0,05\end{array}$} \\
\hline & $\mathrm{K}$ & $66,83 \pm 13,22$ & ,710 & & & & & \\
\hline \multirow[t]{2}{*}{ Posttest } & $\mathrm{E}$ & $79,83 \pm 14,76$ & , 486 & \multirow{2}{*}{907} & & & & \\
\hline & $\mathrm{K}$ & $76,00 \pm 14,04$ & ,649 & & & & & \\
\hline \multirow[t]{2}{*}{$N$-gain } & $\mathrm{E}$ & $0,56 \pm 0,27$ & ,748 & \multirow{2}{*}{,432 } & & & & \\
\hline & $\mathrm{K}$ & $0,31 \pm 0,26$ & ,489 & & & & & \\
\hline
\end{tabular}

Note: $\mathrm{E}=$ Experiment (Practicum Method); K = Control (Discussion Method)

Based on Table 4. Test results for normality and homogeneity of pre-test, post-test, and $\mathrm{N}$-gain cognitive learning outcomes of students in the Experiment and Control class show a significance value higher than 0.05 , meaning that the data are normal distributed and homogeneous. After the normality and homogeneity test, the next hypothesis is tested for $\mathrm{N}$-gain cognitive learning outcomes of students using the Independent Sample t-test. The results of the analysis of the effects showed that there was an influence of using practicum methods on student cognitive learning outcomes showed a value of 0.001 , which was smaller than $0.05\{$ Sig. (2-tailed) $<0.05\}$ with the value of $\mathrm{t}$ calculate $>\mathrm{t}$ table means that $\mathrm{H}_{0}$ is rejected, and $\mathrm{H}_{1}$ is accepted so that it can be interpreted that there is an influence of the use of practicum methods on student cognitive learning outcomes. According to Bruner (1964) believes that one of the factors of cognitive development is the ability of the representation of knowledge even, representation shows a real understanding of words and concepts in a problem. A representation is defined as a configuration of characters, images, icons, tables, graphics, and concrete objects that can represent or represent something else. Meanwhile, according to Nunuk \& Leo (2012), in the teaching-learning process with practicum methods, students are allowed to experience it themselves or do it themselves, follow a process, observe an object, analyze, prove and draw their conclusions.

The percentage change in students 'cognitive learning outcomes between the experimental and control classes has differences that can be seen from the comparison of the $\mathrm{N}$-gain values of student's cognitive learning outcomes. The percentage of dynamic changes in the amount of N-gain cognitive learning outcomes of students who learn using the practicum method is highest in the medium category, while students who use the highest discussion method in the medium category, as shown in Figure 8.

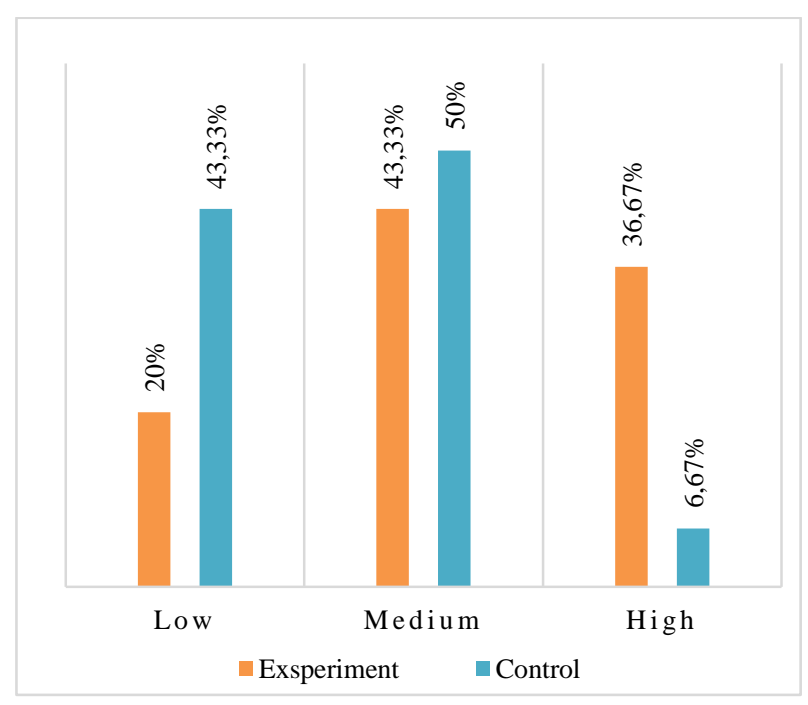

Figure 8. Percentage of Dynamics of Change in N-gain Value of Cognitive Learning Outcomes in Experiments and Control Classes

They are increasing cognitive learning outcomes because students experience learning experiences that can facilitate students in accepting concepts that are found during the practicum, so it is easier to remember and understand. According to Wulandari, Masjhudi, \& Balqis (2014) revealed that the application of learning biology with practicum makes students more active and involved in the learning process so that the concepts easily remembered and help in training the skills of students. In addition, Yuliana \& Hastiana (2019) said that the influence of practicum methods in learning Biology provides improvements in the form of improved cognitive abilities to students. Conversely, students, who use the discussion learning method this can be due to students lacking understanding of learning material, not all group members issue their own opinions and only stick to one or two students in each group. According to Wertheimer (1985) believes that building representations to solve problems directed at the goals of planning, inference, and elaborating students' knowledge for understanding problem solving and thinking skills. 


\section{Conclusion}

The practicum methods affect the ability of student representation with a significance value of 0,000 ( $p<0.05$ ), and the use of practicum methods affects the cognitive learning outcomes of students with a significance value of 0.001 ( $\mathrm{p}<0.05$ ). Practicum methods can be used by science educators to make it easier for students to understand abstract concepts. Science educators can use representation elements so that understanding concepts can last long in student's memories.

\section{References}

Aeni, A. Q. (2017). Keefektifan Pembelajaran Praktikum Berbasis Guided inquiry Terhadap Keterampilan Laboratorium Siswa. CiE (Chemistry in Education), 6(1), 8-13.

Ainsworth, S. (2006). DeFT: A Conceptual Framework for Considering Learning With Multiple Representations. Learning and Instruction, 16(3), 183-198. https://doi.org/10.1016/j.learninstruc.2006.0 3.001

Bruner, J. S. (1964). The course of cognitive growth. American Psychologist, 19(1), 1-15. https://doi.org/10.1037/h0044160

Fitriyana, D. N. (2013). Pengaruh Pembelajaran Kimia Dengan Metode Student Team Achievement Division (STAD) yang Dilengkapi Eksperimen Laboratorium Riil dan Virtual Terhadap Prestasi Belajar pada Materi Pokok Koloid Ditinjau dari Kemampuan Memori Siswa Kelas XI IA SMA N 8 Surakarta Tahun Ajaran 2011/2012. Jurnal Pendidikan Kimia (JPK). 2(3): 134.

Gilbert, J. K. (2005). Visualization in Science Education. Dordrecht, Netherlands. Springer.

Hutagaol, K. (2013). Pembelajaran Kontekstual Untuk Meningkatkan Kemampuan Representasi Matematis Siswa Sekolah Menengah Pertama. Infinity Journal, 2(1), 85-99.

https://doi.org/10.22460/infinity.v2i1.27
Jonathan dan Justin. 2010. Good Practice in Science Teaching. Mc Graw Hill: Open University Press. Page 110-152.

Malik, A., Utami, S. N., Mulhayatiah, D. (2015). Model Praktikum ConcreteRepresentational-Abstract (CRA) Untuk Meningkatkan Keterampilan Proses Sains Siswa. Departemen Pendidikan Fisika, FPMIPA UPI. 5.

Nunuk S. \& Leo A. 2012. Strategi BelajarMengajar. Ombak. Yogyakarta. 7-63.

Permendikbud. (2003). Lampiran Peraturan Menteri Pendidikan dan Kebudayaan Republik Indonesia Nomor 20 Tahun 2003 Tentang Sistem Pendidikan Nasional. Kemendikbud. Jakarta.

Rosengrant, D., Etkina, E., \& Heuvelen, A. V. (2007). An Overview of Recent Research on Multiple Representation. AIP Conference Proceedings. 149-152. https://doi.org/10.1063/1.2508714

Ruseffendi, E. T. (1996). Pengantar kepada Mengembangkan Kompetensi Guru Matematika untuk Meningkatkan CBSA. In Tarsito.

https://doi.org/10.3844/jssp.2010.272.275

Schoenfeld, A. H. (2013). Cognitive science and mathematics education. In Cognitive Science and Mathematics Education. https://doi.org/10.4324/9780203062685

Sugiyono. (2010). Metode Penelitian Pendidikan Pendekatan Kuantitatif, Kualitatif dan R\&D. Alfabeta. Bandung.

Wertheimer, M. (1985). A Gestalt perspective on computer simulations of cognitive processes. Computers in Human Behavior, 1(1), 19-33. https://doi.org/10.1016/0747-5632(85)90004$\underline{4}$

Wulandari, V., Masjhudi, \& Balqis. 2014. Penerapan Pembelajaran Berbasis Praktikum untuk Meningkatkan Keterampilan Proses Sains dan Penguasaan Konsep Siswa Kelas XI IPA 1 di SMA Muhammadiyah 1 Malang. Jurnal Pendidikan Sains. 3(1):7.

Yuliana, I \& Hastiana, Y. (2019). Peningkatan Kemampuan Kognitif Siswa Melalui Metode Praktikum dengan Media 
The Effect of Practicum Method on Representation Ability and Cognitive Learning Outcomes

Powerpoint Interaktif. Jurnal Penelitian

Pendidikan Biologi. 3(1): 22.

Zahrah, F., Abdul H., dan Hasan, M. (2017). Penerapan Praktikum Dengan Model Problem Based Learning (PBL) Pada Materi Laju Reaksi Di SMA Negeri 1 Lembah Selawah. Jurnal Pendidikan Sains Indonesia. 5(2):117-188. 